\title{
PROJECT MANAGEMENT DIAGNOSTIC IN A RESEARCH CENTER USING THE CURRENT REALITY TREE METHOD
}

Isabela Neto Piccirillo (isabela.piccirillo@usp.br) - São Carlos School of Engineering, University of São Paulo, EESC/ USP

Sergio Luis da Silva (sergiol.ufscar@gmail.com) - Federal University of São Carlos, UFSCar

Daniel Capaldo Amaral (amaral@sc.usp.br) - São Carlos School of Engineering, University of São Paulo, EESC/ USP

Eduardo Bellini Ferreira (ebferreira@sc.usp.br) - Center for Research, Technology and Education in Vitreous Materials, CeRTEV, São Carlos School of Engineering, University of São Paulo, EESC/ USP

\section{ABSTRACT}

University research centers must manage projects for technological research that broadens the knowledge frontier as well as deal with industrial partners to foster entrepreneurship and always plan deliveries demanded by funding agencies. The literature addresses the necessity of project management skills and methods to minimize challenges. However, few studies bring the perceptions of the internal stakeholders. This paper analyzed and raised the main challenges of project management in one research center using the Current Reality Tree method through a case study. As a result, it was possible to verify three leading root causes of difficulties on project management, planning and controlling, and communication with funding agencies.

Keywords: Current Reality Tree, Diagnostic, Project Management, Research Center 


\section{INTRODUCTION}

The university's traditional mission of just developing and transmitting knowledge has changed (ETZKOWITZ, 2013, VISHNEVSKIY et al. 2016). There is a growth in the number of research projects involving government and industries to deliver innovative solutions to wicked issues (THOMASSON; KRISTOFERSON, 2020). It means the academic research collaboration becomes cross-sectorial (BOARDMAN; PONOMARIOV, 2012).

The value of skills and competencies related to project management has been argued (FERNANDES et al., 2020, CUNNINGHAM et al., 2015). It is necessary to plan deliveries, budget, level of quality and define tangible and intangible values by key stakeholders (FERNANDES et al., 2020). On the one hand, it is challenging to define each authors' objectives and expectations for effective collaboration (ADLER et al., 2009; CUNNINGHAM et al., 2015). On the other hand, internal stakeholders at research centers have project management difficulties to deliver reports for financial control and performance indicators (BOZEMAN; BOARDMAN, 2004; PERKMANN; WALSH, 2007) as well as manage technological entrepreneurship (SIMEONE et al., 2017).

In this way, it is necessary to understand the challenges and difficulties in project management from different perspectives (ADLER et al., 2009; CUNNINGHAM et al., 2015). There are articles exploring project management challenges: between university-industry collaboration (SJÖÖ; HELLSTRÖM, 2021, DE SILVA et al, 2021), for Principal Investigators-PIs project management (CUNNINGHAM et al, 2015, BOARDMAN; PONOMARIOV, 2012, O'REILLY et al., 2010) project management boundary-spanning with all internal stakeholders -researchers and colleagues, Ph.D. students; research manager (ADLER et al., 2009). However, there are few studies diagnosing challenges in university research centers using Project Management Guide (GREENE, 2010), and few or no articles with cause-and-effect relationships for internal stakeholders' challenges in project management.

We conducted a case study in an international research center to diagnose the project management challenges in university entrepreneur context through the cause-and-effect method called Current Reality Tree (CRT), more specifically, the Diagile method (COSTA et al., 2011). This method is supported to shed light on internal and external factors that affect the research center management and support the prioritization of root causes. 


\section{PROJECT MANAGEMENT IN RESEARCH CENTERS}

The research program is surrounded by internal stakeholders (Principal Investigators-PIs; researchers and colleagues, Ph.D. students) and by external stakeholders (Funding Agencies; Industrial partners; Academia) (ADLER et al., 2009).

Research center's internal stakeholders are defined with bureaucratic (LEE, 2008) and coordination activities in university-industry-government interactions (BOARDMAN; PONIMARIOV, 2012), at the same time they are evaluated on scientific publications (ADLER et al., 2009).

The cultural disparity of industries and research centers' formal and informal management environments, respectively, can cause conflicts due to less space for autonomy and experimentation in their interaction (DU et al., 2014). According to Fernandes (2014), it is not just necessary to implement project management, but also to demonstrate the value of these practices to the stakeholders for an effective consortium. The research centers traditionally focus on development pushed by the technology, while industries are guided by the market (CHANG et al., 2017).

Due to the management challenges, internal stakeholders need the skills to integrate the whole team effectively in such a complex, unpredictable environment (CASATI; GENET, 2014), besides the formal reporting and accountability (PIUNNO et al., 2014). There are studies about fittable project management methodologies for this context.

\section{METHOD}

An explanatory case study is recommended for several reasons. First, this method is the most suitable research approach for contemporary events with no control over the environment and to investigate managerial tasks of internal stakeholders in real life (YIN, 2009, VOSS et al., 2002), allowing for diagnosing the project management central challenges in a research center.

The research center was selected following three criteria: i) university-industry collaboration; ii) technological entrepreneurship fostering; and, iii) funding agencies sponsoring. Data were collected through semi-structured interviews with its Coordinator, Principal Investigators, Ph.D. students, and secretaries responsible for bureaucratic management. Data analysis is based on the Current Reality Tree and the Diagile method. 
The Current Reality Tree is constructed to establish a stream of cause-and-effect logical relationships, linking the core conflict with the undesirable effects (UE) (Reid and Cormier, 2003). The CRT aims to answer three questions: i) what to change, ii) to change to what, and iii) how to change.

According to Costa et al. (2011), the Diagile approach is a diagnostic method based on CRT that incorporates best project management practices. The CRT and case study steps are shown in Figure 1.

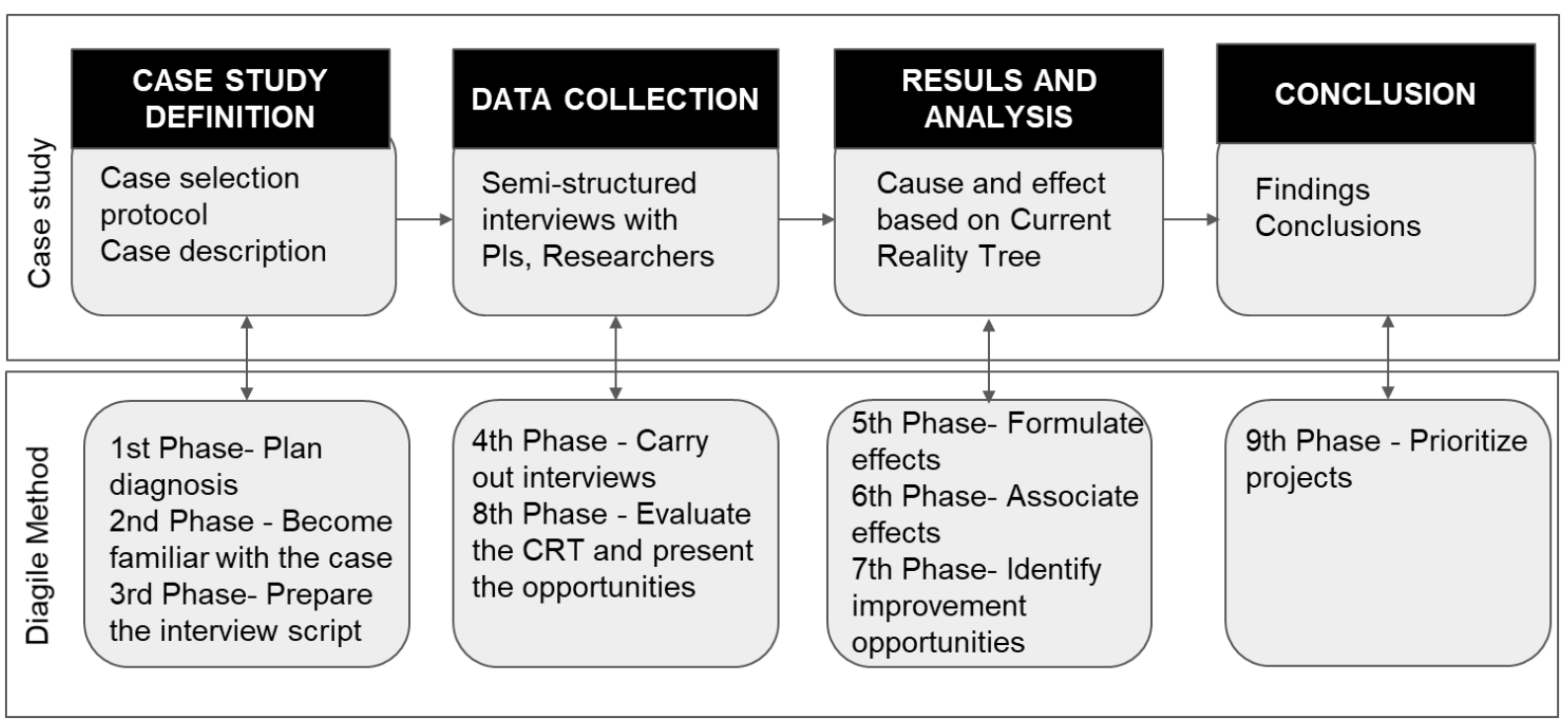

FIGURE 1- Diagile method and case study steps

The Diagile $1^{\text {st }}$ step (or phase) plans the diagnosis by defining the interviewers and the main deliverables. This step must consider opinions from different players to develop a complete diagnosis. In the $2^{\text {nd }}$ phase, interviewers must familiarize themselves with the organization, collecting information for a preliminary analysis. In the $3^{\text {rd }}$ phase, the interview scripts are prepared, looking to obtain the information required for the CRT. In the $4^{\text {th }}$ phase, the interviews are carried out. In the $5^{\text {th }}$ phase, the undesirable effects are formulated. In the $6^{\text {th }}$ phase, such effects are associated with each other following the structure: "If it causes .... THEN ... (effect)". In this way, the $7^{\text {th }}$ phase is carried out to check for improvements in the effects. If some are identified, they must be included. In the $8^{\text {th }}$ phase, the involved organization and professionals evaluate the resulting CRT. Finally, the projects are prioritized through previously defined criteria.

The next sessions are divided according to the case study steps and with Diagile content. 


\section{CASE STUDY DEFINITION}

One case study was conducted in an international research center (Center for Research, Technology, and Education in Vitreous Materials, CeRTEV) with 14 principal investigators, one education expert, members of its advisory board, and about 50 research students from three universities. CeRTEV initiated operation in 2013 with approximately USD 22 million effort by a Brazilian funding agency (FAPESP) until 2024. It aims to develop glass and glassceramic materials for applications on tough structures (e.g., dental prostheses and armors), medicine, architecture and construction, optics (laser glasses), electrochemical energy storage devices (electrolytes, high-temperature seals), and catalytically active systems (CERTEV, 2021).

Initially, we spent one week in the research center to familiarize ourselves with the process, challenges, and preliminary analysis. Thus, with the help of some CeRTEV's members, we defined who would be interviewed, preparing an interview script about ten knowledge areas to map a Project Management Guide: scope, integration, time, costs, quality, human resources, communication, risks, procurement, stakeholders. We planned to interview representatives of all kinds of internal stakeholders for a holistic and neutral perspective of this research center's project management.

\section{DATA COLLECTION}

Firstly, we participated in two management meetings to understand how the internal stakeholders share the tasks and challenges. Next, the research manager was interviewed to comprehend how he manages the research center. Then, the interviewer spent five days watching the secretaries, aiming to understand their routines. A semi-structured questionnaire was developed with the collected information with questions about the ten knowledge project management areas. Thirteen PIs, four Ph.D. students, and the Center manager were interviewed individually, the other interviews were in a group with discussion, as shown in Table 1.

TABLE 1. Data collection of the study case

\begin{tabular}{|c|c|c|c|}
\hline Data collection & $\begin{array}{c}\text { \# of } \\
\text { Interviews }\end{array}$ & $\begin{array}{c}\# \text { of } \\
\text { interviewers }\end{array}$ \\
\hline
\end{tabular}




\begin{tabular}{|l|c|c|c|}
\hline $\begin{array}{l}\text { Research } \\
\text { manager }\end{array}$ & $\begin{array}{c}\text { Semi-structured interview, } \\
\text { Participant observation }\end{array}$ & 4 & 1 \\
\hline Ph.D. students & Semi-structured interview & 4 & 7 \\
\hline $\begin{array}{l}\text { Principal } \\
\text { Investigators }\end{array}$ & $\begin{array}{c}\text { Semi-structured interview, } \\
\text { Participant observation }\end{array}$ & 19 & 13 \\
\hline Secretaries & Participant observation & 5 & 2 \\
\hline
\end{tabular}

At the end of the CRT development, the researcher presented the results to the participants and collected feedback. The final CRT was also presented to three management professionals to validate the method and the cause-effects. The first professional has more than 20 years of experience as a project manager in a multinational. The second professional, with experience as a project manager and theoretical knowledge about project management. In this way, it was possible to validate the cause-effect challenges according to theoretical and empirical project management practices. The second professional has more than ten years of experience as a quality coordinator in a multinational and validated the perspective of the CRT method.

\section{RESULTS AND ANALYSIS}

The interviews were transcribed, and the undesirable effects (UEs) were formulated. Each UE was written in one post-it and divided according to the ten areas of the Project Management Guide. The UEs were prioritized by the recurrence among the interviewees. The main effects were used as starting points to follow the UEs until a root cause, as shown in Figure 3. Three main effects were identified

Effect 1 - Few integrating projects with the effective participation of researchers. Most interviewees mentioned this main effect.

According to them: "The funding agencies encourage us to develop projects with more than one researcher. But we don't know how to use our abilities to integrate projects". Most of them did not know what the other PIs or Ph.D. students were researching: "I just know the research lines but specifically in what I have no idea. Maybe I could help or be helped if I knew more about it ". A specific situation happened with one PI: "Once I went to a congress and realized that one PI of the same center was researching what I was doing exactly." Four PIs have the same opinion: "We should build a common goal 
while we have a lot of financial resources" and nine PIs: "I would like to integrate with the other colleagues effectively."

Effect 2 - Situations with no refund by the funding agencies. According to eight of eleven PIs interviewed, it is difficult to know the criteria the funding agency considers to approve accountability:

"They constantly change the rules. One year they paid a taxi for the visiting researchers; in another year, they didn't. This lack of information means that we always have to pay something out of our pocket". According to some PIs, the communication with the funding agencies is inefficient: "I need equipment, I have money, but sometimes I cannot buy it because of the bureaucracy." One PI emphasized that a solution could be better communication with the funding agency: "We need more communication and contact with them for discussing and understanding the bureaucratic activities."

Effect 3 - Few Ph.D. for some areas. According to five PIs, another difficulty is the lack of human resources:

"The funding agencies have denied more Ph.D. scholarships. They are using excuses such as graduation notes, lack of international experience". In addition, three PIs explained that some selective processes for Post-doc grants take too long: "Sometimes we have the perfect postdoc with abilities and knowledge for studying a rare technology. But it takes a lot to approve in the selective process. Thus the applicant tries other opportunities, and we stay with none".

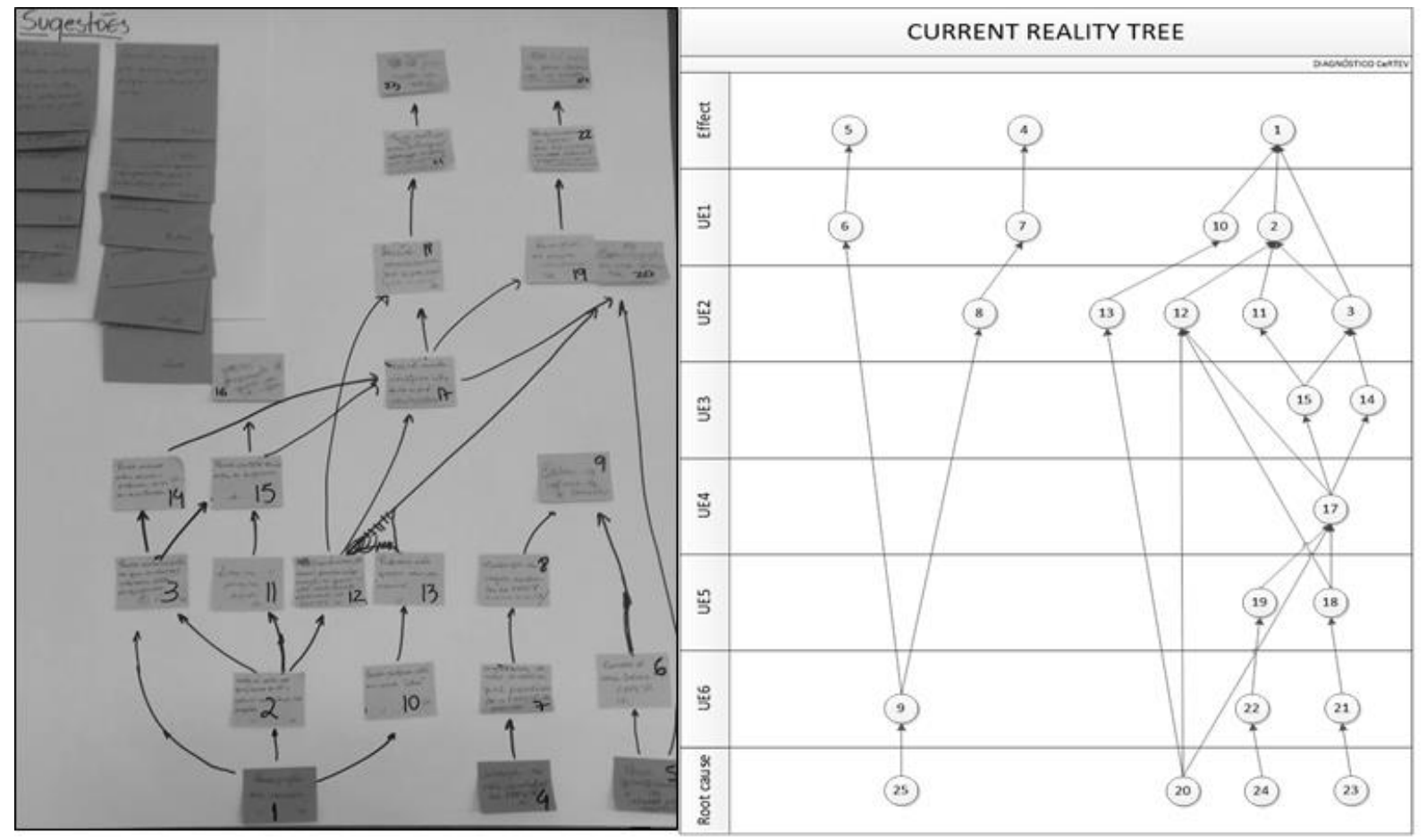

FIGURE 2 -- Current Reality Tree of the study case 
Identifying the main effects, the UEs were connected following the structures: "IF cause ... THEN effect". In addition, the tree was checked several times for the pertinence of the causal relationships or the need for another UE to improve consistency. As a result, the identified root causes were:

- Few communications with funding agency;

- $\quad$ Few projects planning and control; and

- Few integrate multidisciplinary projects.

After finishing the CRT, it was necessary to present and evaluate it. Firstly, it was shown to three quality and project management experts who approved the UEs and the respective solutions. Then, the internal stakeholders went through a workshop. The participants had to understand the cause and effect of the challenges and prioritize with a stick the primary root cause, considering the viability of the solution. The selected root causes should depend on internal stakeholders only.

Despite the importance, the root cause concerning the funding agency's management was not selected. The traditional communication and the reports requested by the funding agency were already carried out and approved. This root cause is focused on changing how funding agencies manage the documents and indicators of the research centers. As it is a top-down decision that directly involves the agencies, it was suggested, in future events, to search alternative communication channels with key people to make faster and more explicit instructions for managing project resources.

The other two root causes were interconnected, i.e., the lack of control and project planning makes it challenging to develop multidisciplinary projects. According to one PI, "If it is already difficult to follow a plan in my research, imagine developing a joint project, with partners' dependencies."

According to those involved in the workshop: "We need someone to teach us some tools or methods that would enable management in this uncertain environment and monitor several researchers with a common focus. It would be a great solution."

In this way, the focus to minimize the root causes would be on methods or tools capable of supporting technology management. These places have a dynamic and flexible environment with strict control of development agencies that must be reported in pre-established deadlines about the center's status. Therefore, developing appropriate practices and tools for research 
centers monitoring projects and scheduling essential tasks is necessary, enabling it to elaborate multidisciplinary projects aligned with its core strategies.

\section{DISCUSSION}

The first root cause is about few multidisciplinary projects. Managing an interdisciplinary, interdepartmental program with researchers from different disciplines, universities, cities and, sometimes, from other countries is challenging. The involved researchers working together in common goals with only a few opportunities for sharing experiences increases the chance of unsuccessful multidisciplinary projects. Besides that, there are other challenges that aggravate this development, such as the relationship between stakeholders, lack of alignment of expectations.

This root cause corroborates with authors that address the necessity of identifying methods, techniques, or tools that enable the development of joint projects (MASCARENHAS et al., 2017), ensuring multi-level planning and monitoring, and value generation for the market and society (BROCKE, LIPPE, 2015).

An alternative to foster common goals on product or technology development is technology roadmapping (TRM), as already applied in triple helix context (Zhang et al., 2016). Phaal et al. (2004, p. 10) define a TRM as a time-based chart comprising several layers that typically include commercial and technological perspectives. The TRM enables exploring the evolution of markets, products and technologies together with the linkages and discontinuities from various perspectives, aiming to answer three key questions: i) where are we now, ii) where do we want to get to, and iii) how can we get there?

The approach pushed by technology focuses more on the shared vision of technological development than on the market and product attractiveness (Lee et al., 2009). Some studies show that roadmapping is beneficial at research centers for proper information exchanging between partnerships from different companies (AMADI-ECHENDU et al., 2011), communication (MA et al. 2006), and increasing the level of creativity and problem-solving ability (MOHAN; RAO, 2005).

The other root cause is the little project planning and control. There are some studies that address the necessity to develop specific practices for these uncertain, flexible environments. Piunno et al. (2014) argued that Agile Project Management (APM) could be a solution for project management, teamwork and multidisciplinary education. APM is a set of techniques 
designed to give agility to project management. It is an approach based on principles, values, and practices whose objective is to simplify project management, reaching more flexibility and interactiveness with less management effort, higher levels of innovation, and more valueadded to customers (CONFORTO et al., 2014). In this way, APM can help facing challenges on project planning with dependencies in different partners. When project management is done by the team and not just by the leading researcher, this could help solve the overwork, prioritize the research demands and simplify controls. The APM could also help research centers solve the root cause of little planning and project control. Furthermore, some studies have shown that APM can be used with roadmapping (CARLOS et al. 2018, DE SOUZA et al. 2021).

\section{CONCLUSION}

This paper makes theoretical and practical contributions to understanding the challenges of the research center management. The first theoretical contribution is to advance the understanding of the effects and root causes based on the Current Reality Tree developed in an international and well known research center.

The second contribution is the development of possible solutions in project management to bring more multidisciplinary projects and projects planning and control. It could be supported by technology planning, i.e. technology roadmapping. It allows the internal as well as external stakeholders to plan the project vision together, aligning expectations and dealing with each partner's contribution and development dependencies. There are studies about roadmapping development for university-industry collaboration. Moreover, it could support the internal stakeholders' collaboration defining the main partner, skill's necessity, equipment with a strategic view. Another solution for this uncertain and flexible environment is agile project management practices to support PIs, research in collaborations without loose times for improvisation and creativity.

The third theoretical contribution is to adapt the Current Reality Tree using post-its to bring agility in its development. The fourth contribution is practical. We have demonstrated how specific practices (roadmapping and APM) can support project management challenges in a research center. However, more investigations are needed to prove the efficacy and efficiency of these hypotheses to confirm or reject them. 
The main limitation of the case study was the diagnosis from a few internal stakeholders' perspectives and only one academic research center. Thus, studies with other research centers and including external stakeholders' perceptions are necessary to improve the diagnosis of managing challenges in collaboration projects joining industries, universities and funding agencies.

\section{ACKNOWLEDGMENTS}

The authors gratefully acknowledge the support from the São Paulo Research Foundation FAPESP - CeRTEV grant 2013/07793-6. This study was financed in part by the Coordenação de Aperfeiçoamento de Pessoal de Nível Superior - Brasil (CAPES). We also thank CeRTEV for its partnership with this research.

\section{REFERENCES}

ADLER, N., ELMQUIST, M. NORRGREN, F. "The Challenge of Managing BoundarySpanning Research Activities: Experiences from the Swedish Context", Research Policy, v. 38(7), p. 1136-1149, 2009.

BARNES, T. A., PASHBY, I. R. GIBBONS, A. M. "Managing collaborative R \& D projects development of a practical management tool", International Journal of Project Management, v. 24 (5), p. 395-404, 2006.

BAGLIERI, D. ,LORENZONI, G. "Closing the distance between academia and market: Experimentation and user entrepreneurial processes" Journal of Technology Transfer, v. 39 (1), p. 52-74, 2014.

BOARDMAN, C. ,PONOMARIOV, B. "Management knowledge and the organization of team science in university research centers", Journal of Technology Transfer, V. 39, p. 7592, 2012.

BOZEMAN, B. AND BOARDMAN, C. "The NSF Engineering Research Centers and the University-Industry Research Revolution: A Brief History Featuring an Interview with Erich Bloch" Journal of Technology Transfer, V. 29, p. 365-375, 2004.

BUSHE, G. R., MARCHAK, R. J" Revisioning Organization Development: Diagnostic and Dialogic Premises and Patterns of Practice" Journal of Applied Behavioral Science, V. 45 (3), p. 348-368, 2009. 
CARLOS, D. C. AMARAL, M. CAETANO, "Framework for continuous agile technology roadmap updating," Innovation \& Management Review, vol. 15, no. 3, pp. 321-336, 2018

CASATI, A., GENET, C. "Principal investigators as scientific entrepreneurs", Journal of Technology Transfer, V. 39(1), p. 11-32, 2014.

CONFORTO, E., F. SALIM, D. C. AMARAL, S. L. DA SILVA, L. F. M. DE ALMEIDA, "Can Agile Project Management Be Adopted by Industries Other than Software Development?," Project Management Journal, v. 43 (2), p. 84-100, 2014.

COSTA, J. MH; AMARAL, C. S. T. ; ROZENFELD, H. Proposal of a NPD diagnostic method to identify improvement opportunities. In: Concurrent Engineering, 2011, Boston. Concurrent Engineering, 2011

CERTEV (2020) Available at: http://www.certev.ufscar.br/

CUNNINGHAM, J., REILlY, P., KANE, C. MANGEMATIN, (2015) "Managerial Challenges of Publicly Funded Principal Investigators" International Journal Technology Management, v. 68, p. 176-202., 2015.

DE SILVA, Muthu et al. Does affective evaluation matter for the success of universityindustry collaborations? A sentiment analysis of university-industry collaborative project reports. Technological Forecasting and Social Change, v. 163, p. 120473, 2021.

DE SOUZA, MATHEUS LUIZ PONTELO et al. Agile Roadmapping: A management Tool for Digital Entrepreneurship. IEEE Transactions on Engineering Management, 2020.

DU, J.; LETEN, B.; VANHAVERBEKE, W. "Managing open innovation projects with science-based and market-based partners". Research Policy, v. 43 (5), p. 828-840, 2014.

FERNANDES, G., O' SULLIVAN, D., PINTO, E.B., ARAÚJO, M MACHADO, R.J., "Value of project management in university-industry R\&D collaborations", International Journal of Managing Projects in Business, V. 13 (4), p. 819843, 2020.

GREENE, Joseph. Project management and institutional repositories: A case study at University College Dublin Library. New Review of Academic Librarianship, v. 16, n. S1, p. 98-115, 2010.

HEATH, T. A quantitative analysis of PhD students' views of supervision. Higher Education Research and Development, v. 21, p. 37-41, 2002. 
LEE, A. "How are doctoral students supervised? Concepts of doctoral research supervision" Studies in Higher Education, v. 33 (3), p. 267-281, 2008

NOMAKUCHI, T.; TAKAHASHI, M. (2015) "A Study about Project Management for Industry-University Cooperation Dilemma" Procedia Computer Science, v. 64, p. 47-54, 2015.

PERKMANN, M.; WALSH, K. "University-industry relationships and open innovation: Towards a research agenda". International Journal of Management Reviews, v. 9 (4), p. 259-280, 2007.

PIUNNO, P., BOYD, C., BARZDA, V., GRADINARU, C., KRULL, U., STEFANOVIC, S., STEWART, B. The Advanced Interdisciplinary Research Laboratory: A Student Team Approach to the Fourth-Year Research Thesis Project Experience. Journal of Chemical Education, v 91(5), p. 655-661, 2014.

POLE, C. J., SPROKKEREEF, A., BURGESS, R., LAKIN, E. "Supervision of Doctoral Students in the Natural Sciences: expectations and experiences" Assessment \& Evaluation in Higher Education, v 22 (1), p. 49-63, 2006.

PORTNY, E. AUSTIN, J. "Project Management for Scientists" Science Journal, p. 1-3, 2002 O'REILLY, P., O'KANE, C., CUNNINGHAM, J., MACIOCHA, A., MANGEMATIN, V." Project Formation and the Motivations and Challenges of the Principal Investigator Role in Publicly Funded Research" Technology Transfer Society Annual Conference, Washington DC, USA, 2010.

REID, RA, CORMIER, JR (2003)," Applying the TOC TP: a case study in the service sector", Managing Service Quality: An International Journal, v 13(5), p.349 - 369, 2003

SJÖÖ, K.; HELLSTRÖM, T. The two sides of the coin: joint project leader interaction in university-industry collaboration projects. R\&D Management, 2021.

THOMASSON, A.; KRISTOFERSON, C. W.. Hybridizing the Triple Helix: A prerequisite for managing wicked issues. Financial Accountability \& Management, v. 36, p. 207-222, 2020.

ULRICH, W, DASH, D. P. "Research Skills for the Future: Summary and Critique of a Comparative Study in Eight Countries", Journal of Research Practice, V9(1), 2013. 
VOSS, C., TSIKRIKTSIS, N AND FROHLICH, M. Case Research in Operations Management. International Journal of Operations and Production Management, v 22 (2), p. 195-219, 2002.

ZHANG, Yi et al. Technology roadmapping for competitive technical intelligence. Technological Forecasting and Social Change, v. 110, p. 175-186, 2016. 